\author{
Чень Менмен, \\ аспірант Харківської державної академії культури \\ ORCID 0000-0000-0436-7750
}

\title{
ХУАН ЦЗИ - КОМПОЗИТОР І ВЧЕНИЙ: ТВОРЧІ ЗВЕРШЕННЯ ФУНДАТОРА НАЦІОНАЛЬНОЇ МУЗИЧНОЇ КИТАЙСЬКОЇ КУЛЬТУРИ НОВІТНЬОЇ ДОБИ
}

Мета статті - виявити масштаби творчих звершень Хуан Цзи - китайського Шуберта, композитора та вченого - у процесі формування основ національної музичної китайської культури Новітньої доби. Методологія дослідження базується на застосуванні методу історизму, системного аналізу, застосованого з метою встановлення сукупного значення видів науково-творчої діяльності Хуан Цзи у формуванні новітньої музичної культури Піднебесної; задіянні жанрово-стильового аналізу з метою визначення досягнень Хуан Цзи - композитора у процесі формування основ професійної музичної культури Китаю XX століття. Наукова новизна полягає у визначенні значення науково-творчої діяльності Хуан Цзи - вихователя першого композиторського покоління китайських композиторів, які залучили до власної творчості європейські традиції - у процесі формування жанрово-стильових та науково-педагогічних засад професійної музичної культури Китаю першої третини XX століття; жанрово-стильових відкриттів композитора у формуванні основ вокальної та інструментальної музики Піднебесної (зокрема, у сфері поліфонії), китайського трагічного та ліричного стилів у музичному мистецтві; встановленні значення спадку вченого, який заклав основи історичного та теоретичного музикознавства, музичної естетики та педагогіки Китаю. Хуан Цзи як фундатор сучасної музично-теоретичної китайської думки значну увагу приділив питанню взаємодії «чистої» («ідеальної») та програмної музики, зв’язків музики і повсякденного життя. Головне завдання музики як «великого мистецтва», за Хуан Цзи, - створення «портрету народу і суспільства». Висновки. Хуан Цзи - новатор і класик національного музичного мистецтва, фундатор новітньої музичної школи Китаю - заклав основи професійної музичної освіти Піднебесної, системно охопивши ії напрями. Деякі твори композитора й досі мають унікальне значення в історії китайської музики: якщо жанровою настановою китайської художньої пісні є звернення до національної поезії, то Хуан Цзи заклав перспективи розвитку жанру й на основі застосування іноземної (англійської) мови.

Ключові слова: національна китайська музична культура, китайський Шуберт, фундатор професійної музичної культури Китаю, жанрово-стильова система вокально-хорового та інструментального мистецтва, китайський трагічний та ліричний стилі у музичному мистецтві, китайська «чиста» та програмна музика.

Чень Менмен, аспирант Харьковской государственной академии культурьл

Хуан Цзы - композитор и ученый: творческие свершения основоположника национальной музыкальной китайской культуры Новейшего времени

Цель статьи - выявить масштабы творческих свершений Хуан Цзы - китайского Шуберта, композитора и ученого - в процессе формирования основ национальной музыкальной китайской культуры Новейшей эпохи. Методология исследования базируется на методе историзма, системного анализа, примененного с целью установления совокупного значения видов научно-творческой деятельности Хуан Цзи в формировании новейшей музыкальной культуры Поднебесной; введен жанрово-стильовой анализ с целью опрелеления достижений Хуан Цзыкомпозитора в процессе формирования основ профессиональной музыкальной культуры Китая ХХ века. Научная новизна заключается в определении значения научно-творческой деятельности Хуан Цзы - воспитателя первого композиторского поколения китайских композиторов, которые вовлекли в свое творчество европейские традиции, - в процессе формирования жанрово-стилевых и научно-педагогических основ профессиональной музыкальной культуры Китая первой трети XX столетия; жанрово-стилевых открытий композитора в области вокальной и инструментальной музики Поднебесной (в частности, в сфере полифонии), китайского трагического и лирического стилей в музыкальном искусстве; значения наследия ученого, который заложил основы исторического и теоретического музыковедения, музыкальной эстетики и педагогики Китая. Хуан Цзи как основоположник сосременной музыкальнотеоретической китайской мысли значительное внимание уделил вопросу взаимодействия «чистой» («идеальной») и программной музыки, связям музыки и повседневной жизни. Главная задача музыки как «великого искусства», по Хуан Цзы, - срздание «портрета народа и общества». Выводы. Хуан Цзы - новатор и классик национального музыкального искусства, основоположник новейшей музыкальной школы Китая - заложил основы профессионального музыкального образования Поднебесной, системно охватив ее направления. Некоторые произведения композитора до сих пор имеют уникальное значение в истории китайской музыки: если жанровой основой китайской хужественнй песни является обращение к национальной поэзии, то Хуан Цзы заложил перспективы развития жанра и на основе обращения к иностранному (английскому) языку.

Ключові слова: национальная китайская музыкальная культура, китайский Шуберт, основоположник профессиональной музыкальной культуры Китая, жанрово-стилевая система вокально-хорового и инструментального искуссттва, китайский трагический и лирический стили в музыкальном искусстве, китайская «чистая» и программная музика.

(ОЧень Менмен, 2019 

Culture

Chen Mengmeng, postgraduate of the Department of Theory of Music and Piano, Kharkiv State Academy of

Huang Ji - composer and scholar: creative achievements of the founder of the chinese national music culture in the contemporary world

The purpose of the article is to reveal the degree of Huang Ji's creative achievements - the Chinese Schubert, composer, and scholar - on the make of the foundations of the Chinese national music culture in the contemporary world. Methodology is based on the method of historicism, system analysis, applied to define the combined value of types of research and creative activities of Huang $\mathrm{Ji}$ in the formation of the newest music culture of the Middle Kingdom; a genre and style analysis was introduced to identify the achievements of Huang Ji-the composer on the make of the foundations of the professional music culture of China of the twentieth century. Scientific novelty. An attempt is made at defining the importance of Huang Ji's research and creative activities - the educator of the first generation of Chinese composers who involved European traditions in their work - on the make of the genre and style and educational research foundations of the professional music culture of China in the first third of the twentieth century; the genre and style discoveries of the composer in the field of vocal and instrumental music of the Middle Kingdom (in particular, in the field of polyphony), Chinese tragic and lyrical styles in the art of music; the significance of the body of work of the scholar who laid the foundations of historical and theoretical musicology, music aesthetics and pedagogy of China. Huang Ji, as the founder of contemporary music and theoretical Chinese thought, focused extensively on the issue of the interaction of "pure" ("ideal") and descriptive music, the links of music, and everyday life. The main task of music as "great art," according to Huang Ji, is the creation of a "portrait of a nation and society." Conclusions. Huang $\mathrm{Ji}$ is an innovator and classic of national art of music, the founder of the newest music school in China, who has laid the foundations of the professional music education of the Middle Kingdom, systematically embracing its genres. Some works of the composer still have a unique value in the history of Chinese music: if the genre basis of a Chinese artistic song is an appeal to the national poetry, then Huang Ji has laid the prospects for the development of the genre on the basis of an appeal to a foreign (English) language.

Key words: Chinese national music culture, Chinese Schubert, founder of the professional music culture of China, genre and style system of vocal and choral and instrumental art, Chinese tragic and lyrical styles in the art of music, Chinese "pure" and descriptive music.

Актуальність теми дослідження. Життя Хуан Цзи (1904 - 1938) - «піонера сучасної музики», «новатора і великого фундатора національної музичної школи Китаю» [3], музичного діяча, декана Шанхайської консерваторії, педагога, вченого, першого професійного композитора, очільника периої класичної національної традииї музичного мистецтва - було надто коротким, але значення його творчого спадку у процесі формування новітньої музичної культури Піднебесної важко переоцінити. Його спадщина має «унікальне історичне значення в розвитку сучасної китайської музики» [3]. Хуан Цзи (Huang Zi) став першим музикантом, хто, діставши професійну освіту на Заході (навчався в Європі та США), специфікував принципи європейської композиторської творчості для музичного мистецтва Китаю першої третини ХХ століття, який (за Хе Лютінг [1]), упровадив до національної музичної творчості основи західної композиторської майстерності.

Мета статті - виявити масштаби творчих звершень Хуан Цзи - китайського Шуберта, композитора та вченого - у процесі формування основ національної музичної китайської культури Новітньої доби.

Аналіз останніх досліджень і публікацій. В основу статті покладено оригінальні праці Хуан Цзи (серед них - «Підручник » «ідручник по відродженню вивчення музики» (1933 - 1935), «Погляд 3 пташиного польота на історію розвитку музики на Заході», «Сучасні коментарі», «Музична насолода», «Вираз емоцій у тональностях» «Історія західної музики», «Музика стародавнього Китаю») та роботи китайських дослідників, присвячені вивченню спадку композитора-вченого (зокрема, Хе Лютінг [1], Д’єн Пехай [2], Лю Юйцін [3], Фен Вей [4], Го Ін [5]).

Виклад основного матеріалу. Хуан Цзи - фундатор вокально-хорових та інструментальних музичних жанрів європейського походження у Китаї, заклав основи їх національно-стильового перетлумачення, уведення до національного контексту, виховавши першу плеяду національних композиторів у Шанхайській консерваторії, заклав основи музичної освіти, науки та естетики Піднебесної ХX століття. Досягнення Хуан Цзи в сфері музичної культури Китаю мають широкомасштабний комплескний характер. Започатковані одним 3 перших новаторів у сфері китайської професійної музики напрями й види музичної діяльності й досі постають як основа системи новітньої національної музичної культури. Самий тип музичної освіти на основі застосування принципів консерваторського навчання, уведений Хуан Цзи до національної культури, получив подальший розвиток у Новому Китаї.

Вивчення специфіки творчого внеску Хуан Цзи у національну музичну Китаю першої третини ХХ століття потребує зверення до біографічного методу.

Як зазначає знавець творчого спадку композитора Хе Лютінг, ще у дитинстві майбутній 
композитор відчував тяжіння до народної музики, класичної поезії, літератури. Дитяча захопленість обумовила значеннєвість пісенної творчості у спадку майбутнього композитора, яка, за національною традицією, постає як нероздільна єдність слова і музики. 3 12-річного віку, учнем Пекінської школи Цінхуа, він почав знайомитися з західним музичним мистецтвом, грав на сопілці і фортепіано, співав у хорі і вирішив (попри заборону батька) обрати кар'єру музиканта. 1921 року юний Хуан Цзи, незважаючи на те, що на той час у Китаї професія музиканта вважалася малоперспективною, написав книгу про роль музичної освіти у процесі вдосконалення суспільства, відстоюючи право на власне тяжіння до музичного мистецтва.

Хуан Цзи відноситься до першого покоління музикантів в історії Китаю, яке надавало переваги професійній освіті на Заході - у Америці та Європі - 3 тим, щоби привнести в духовну культуру батьківщини до сих пір невідомі знання. 1924 року Хуан Цзи виїхав до штату Огайо, де у Обердині, який називали містом музики, вивчав основи психології. Саме там, в Обердині, сформувався характер і спосіб мислення майбутнього композитора. Музична атмосфера, яка царювала в Обердині, сприяла наступному, надзвичайно відповідальному рішенню юнака: 1926 року він поступає до Берлінського університету з метою поглибленного вивчення теорії композиції. 1928 року Хуан Цзи переходить до музичного факультету Йєльського університету (консерваторії), де навчається практичним основам музичного мистецтва - оркестровці і композиції. Через рік Хуан Цзи - автор Сонати для фортепіано і Симфонії «Спогади» (як дипломної роботи) - закінчує університет з дипломом бакалавра музики. Хуан Цзи став першим професійним музикантом Китаю, який дістав спеціалізований ступінь 3 теоретичної і практичної композиції у Європі. Його прикладу й досі наслідують молоді музиканти Китаю, що навчаються у різних країнах Європи, спираючись на вироблений класиком національниї музики принцип роботи над музичним твором: «Засвоювати спадок минулого та іноземного» [2]. Завдяки дотримуванню змісту цього принципу, Хуан Цзи здійснив актуальну для китайського музичного мистецтва місію уведення новітніх західних жанрово-стильових тенденцій до традиційної національної творчості.

Через рік після повернення до Китаю (1930р.), Хуан Цзи получив запрошення від ректора Шанхайської вищої музичної школи: молодий професор обіймав посаду декана до кінця своїх днів. За вісім років викладацької діяльності Хуан Цзи виховав представників першого покоління національних композиторів Китаю, які дістали професійну освіту безпосередньо у Шанхаї. Серед учнів Хуан Цзи - видатні композитори, які продовжили розвиток національної вокальної та інструментальної музики, - Чень Тяньхе, Дзян Динсянь, Хе Людін, Лю Шелін, Тан Сялін, Чжан Дін, Цянь Женькан.

Розквіт композиторської творчості Хуан Цзи охоплює 1931 - 1937 роки. За сім останніх років життя композитором були написані найбільш знані й знакові вокальні і та інструментальні твори. Саме цей період в тврорчості китайського Маестро постає як вершинний, кульмінаційний. Стале порівняння Хун Цзи з Францем Шубертом (друге ім'я родоначальника сучасної музичної культури Піднебесної - «китайський Шуберт») обумовлено паралелями як творчого, так і біографічного характеру. Адже земне буття талановитого митця завжди має життєтворчий вимір. Якщо Шуберту судилося прожити 31 рік, то життя Хуан Цзи перервалося у 34 роки. Як і у Шуберта, останній 7 річний період у творчому житті Хуан Цзи набув кульмінаційного значення: саме в останні сім років китайський композитор досяг кульмінації в здійсненні завданя служіння національному мистецтву. Якщо Шуберт заклав основи австро-німецького романтизму, то Хуан Цзи (вихованець Берлінської та Йєльської музичних шкіл) став засновником китайської музичної культури XX століття. Романтична жанрово-стильова складова в іï складі обумовила торжество китайського музичного романтизму першої третини XX століття, що зберіг своє значення й у столітті XXI. Але, поруч з романтизмом, Хуан Цзи як композитор первої третини XX століття спирався й на досвід сучасних йому «західних імпресіоністів», який, зокрема, відчутний в таких китайських художніх піснях, як «Квітка - не квітка» (1933) та «Замок Фу» (1934). Композиторській творчості Хуан Цзи властива єдність не тільки європейських романтично-імпресіоністичних впливів, але й австро-німецьких та французьких жанрово-стильових рис музичного мистецтва.

Хуан Цзи-композитор заклав основи професійної музичної творчості Китаю на основі суміщення композиційних принципів та положень західно-європейської теорії та історії музики із стильовими ознаками китайського народного музичного мистецтва. Хуан Цзи сформував основи жанрово-стильової системи китайського музичного мистецтва, яка упродовж подальших етапів доповнювалася новими жанрово-стильовими одиницями. Хуан Цзи виробив й шляхи адаптації жанрів європейського професйного мистецтва до національної музичної культури, зв'язавши їх 3 основами національної музичної мови, китайскими естетичними ідеалами. 
Серед художніх відкриттів Хуан Цзи у галузі вокально-хорового мистецтва - китайська художня пісня, створена на основі переусвідомлення німецької романтичної Kunstliede, вокальні ансамблі (дуети, тріо, квартети), сольні пісні для дітей та юнацтва, хорові твори великої форми (перша в історії китайської музики ораторія «Одвічна ненависть», 1932 - 1033 [4]), хорові твори різних жанрів (2-х - 4-хголосні), призначені для різних виконавських складів: мішаного хору (приміром, «Національний прапор розвівається» - гімн, що набув значення класичного та став візітною карткою композитора), чоловічого («Барабан юйен») та жіночого («Канонічна пісня», «Гора в ілюзії»). Характерною ознакою хорової творчості Хуан Цзи постає опора на стильові ознаки національного оперного співу. Наприклад, приспів відомого гімну «Національний прапор розвівається», з яким пов'язане затвердження китайського класичного хорового стилю, у процесі розкриття трагічної теми (боротьби з японськими загарбниками, що охопила усю країну), базується на властивій китайській опері принцип єдності всіх видів сценічних виступів («читати, співати, робити, грати»). Оперна сценічність стає жанровою рисою національного хорового мистецтва.

Вокальна творчість Хуан Цзи в жанрі китайської художньої пісні увійшла до скарбниці національних художніх иінностей Піднебесної XX - XXI століть. Композитор сформував своєрідну «Liede-ситуацію» в національній культурі XX століття, заклавши жанрово-стильові ознаки китайської художньої пісні, що й досі визначають її специфіку. Перш за все, сутність жанрово-стильових ознак китайської художньої пісні полягає в органіці взаємодії властивостей Kunstliede і національної мови, тематики, емоції, стилю. До кола жанрових ознак китайської художньої пісні, закладених Хуан Цзи, слід віднести традицію гармонічної взаємодії слова i музики, єдності вокального та інструментального начал як умови народження художньої цілісності поемного типу, музичної поезії. Китайська художня пісня в творчості Хуан Цзи набула функції розкриття внутрішнього світу поетично налаштованого композитора, виразу його гарної літературної освіти та розвиненої музичної уяви.

Хуан Цзи започаткував традицію рівнозначного тлумачення віршів традиційних і сучасних поетів як словесної основи китайської художньої пісні в їі жанрових різновидах. Серед тих поетів, на вірші яких композитор створював вокальні твори - шедеври національної класики, зокрема, Лі Бе («Китайський човен»), Су Ши («Гадатель»), Ван Джуо («Червоні губи»), Синь Чидзі («Сини Півдня на Півночі»), Бай Дзюї («Квітка - не квітка»), а також твори сучасних композиторів поетів, серед яких в творчості Хуан Цзи найпочесніше місце належить Harold H. T. Wei (1905 - 1993). Якщо звернення до віршів класичних поетів у творчості Хуан Цзи обумовлено створенням вокальних творів на «вічні теми» національного мистецтва, то базування пісень на поетичних творах початку XX століття здебільшого обумовлено творчим завданням надання відповіді на «прокляті питання» сучасності. Особливого значення в сольних та хорових творах Хуан Цзи на вірші сучаних поетів набула воєнно-патриотична тематика як вираз національного опору японським загарбникам. Хуан Цзи є родоначальником жанру національної професійної дитячої пісні. Ансамблеві і сольні, а cappell'ні і з супроводом фортепіано, пісні оповідають про свята і повсякденність, ігри та навчання китайських дітей. Зазвичай, прості за формою, дитячі пісні Хуан Цзи - маленькі сцени радісті та печалі - відображують досвід і мудрість поколінь. Винятком у контексті вокальній творчості Хуан Цзи постають чотири вокальних твори англійською мовою (з перекладом китайською); перший 3 них (одноголосний) написаний на слова William Stepenson, інші - на ангійські вірші, написані композитором. Серед вокальних творів Хуан Цзи на англійські вірші (з авторським перекладом) на особливу увагу заслуговують написані в фоліфонічній манері «Vocal Fugue for S.A.T.В.» (для вокального квартету) i «Canon perpetuo a 3 Voci». До вокальних творів Хуан Цзи належать створені на власні вірші китайською у поліфонічному стилі належить хорова «Канонічна пісня». Тяжів композитор і до створення вокальних композицій на основі адаптації народної пісенної поезії (приміром, одноголосна пісня на англійський текст «Song (in folksong style)», дует китайською «Народна пісня Хуайнань»).

У вокальних творах Хуан Цзи склалися два музичних стилі, обумовлених завданням виразу емоційного стану та художнього змісту. Китайський трагічний стиль, призначений для висловлення героїко-патріотчного змісту; китайський ліричний стиль, обумовлений виразом традиційних для китайської поезії станів споглядання пейзажу, крізь спостереження якого розкриваються почуття героя.

Для китайського трагічного стилю у вокальній творчості Хуан Цзи характерний ораторський пафос, маршевість, пунктирна ритміка, кварто-квінтові ходи та рух звуках тризвуку та його обернення (див. пісні «Ворожі солдати», «18 вересня», «Сплячий лев», «Пісня гарячої крові», квартет «Протистояти Японії»). Прообразом китайського трагічного стилю в музиці постає героїчна 
стилістика європейського музичного мистецтва XIX - початку XX століть. Поруч із вагомим значенням європейського прообразу, китайський трагічний стиль, започаткований Хуан Цзи, базується й на національних музичних ознаках. Приміром, жанровим виразом китайського трагічного стилю в пісенній творчості Хуан Цзи постає марш. Якщо пісня «Ворожі солдати» базується на жанрових ознаках європейського маршу (тактовий розмір - 4/4, фанфарні ходи по звуках мажорного тризвуку та його оберненнях, паралельний мажоро-мінор: e-moll - G-dur), то пісня «18 вересня», сама назва якої має символічне значення (дата вторгнення Японії на територію Китаю), спирається на властивості китайського воєнного маршу (дводольність, синкопи, мажорна, а потім й мінорна пентатоніка).

Китайський ліричний стиль у вокальному мистецтві Хуан Цзи вирізняють оповідальність та сповідальність, домінування хвильового типу мелодичного руху, надання фортепіанній партії функції створення психологічного підтексту. Ліричний стиль Хуан Цзи базується на безпосередній взаємодії мелодії і слова. Цей прийом вокальної лірики Хуан Цзи, оснований на підкресленні виразової сили слова мелодичною лінією, визначений Гоу Ін як «слова-копії» [5].

3 творчостю Хуан Цзи пов'язано закладання основ вокальної поліфонії і гармонічного мислення в китайській музиці. Композитор тяжів до різних поліфонічних технік, запозичуючи їх із європейської музичної культури. Приміром, у хоровій двохголосній вокальный міныатюрі «Канонічна пісня» використано техніку канонічної імітації в приму; в дуеті «Народна пісня Хуайнань» спостерігаються риси фугованого розвитку. Сунь Бо - автор праці «Майстерність і стиль вокальних творів Хуан Цзи» - фокусує увагу на акордове мислення композитора, введення вертикалей нетерцової побудови, акордові послідовності, п’ятизвучні акорди.

Хуан Цзи належить честь закладення жанрово-стильових основ національної інструментальної музики, китайського інструментального стилю. Ним були створені перші взірці фортепіанної музики, в яких були закладені iї жанрово-стильові основи, самий звуковий образ китайського фортепіано. Показово, що у фортепіанній творчості композитор звернувся до європейських поліфонічних жанрів і поліфонічного стилю письма, відсутніх у національних традиціях китайського мистецтва. Створені ним у поліфонічному стилі жанри (прелюдія, інвенції, двох- та трьох-голосні фуги на оригінальні теми) сприяли закладенню засад професійного фортепіанного мистецтва країни на основі європейської поліфонічної техніки. Поруч з цим, слід зазначити, що значення поліфонічних творів композитора виходить за межі суто фортепіанноїх музики: тут були закладені основи китайської поліфонічної техніки як такої, застосування яких можливо у творах, призначених для будь-яких складів та жанрів (приміром, у поліфонічній розробці в сонаті).

3 ім'ям Хуан Цзи пов'язано формування основ національної симфонічної музики. Симфонічна п’єса «Ілюзія міського пейзажу», задумана як увертюра до однойменного фільму, продемонструвала вміння композитора мислити оркестрово, володіти оркестровими фарбами. «Ностальгія» (1929) перший китайський «макросимфонічний твір» (за висловом Сюй Цянь), успадковавший європейські традиції музичної мови і романтичну стилістику. Одначе, поруч із значущістю європейських жанрово-стильових прообразів у процесі кристалізації китайського оркестрового стилю, Хуан Цзи не поступився національними традиціями. Базовані на оригінальному тематизмі, оркестрові твори Хуан Цзи стали знаковими у процесі розвитку симфонічного мислення композиторів Піднебесної.

Фортепіанні і Симфонічні твори, написані Хуан Цзи під час навчання на музичному факультеті Йєльського університету, є першими взірцями інструментальних жанрів європейського типу в історії китайської музики. Чан Сяоцзін і Хуан Цзи Лі зазначають, що співвітчизники високо оцінили Симфонічну увертюру Хуан Цзи основоположника національної китайської симфонічної музики.

Хуан Цзи - музичний вчений - заклав основи історії та теорії китайського музикознавства, музичної естетики та музичної педагогіки. Теоретик музичного мистецтва у незавершеній праці «Гармонія» поставив проблеми пристосування західних теоретичних i практичних методів композиції до китайського професіонального створення музики. Внеском до історичного музикознавства Китаю постають такі праці композитора: «Підручник по відродженню вивчення музики» (1933 - 1935), «Погляд з пташиного польота на історію розвитку музики на Заході». Праці «Історія західної музики» і «Музика стародавнього Китаю» залишилися лише у вигляді нарисів.

У працях «Сучасні коментарі», «Музична насолода», «Вираз емоцій у тональностях» Хуан Цзи у відповідності до розвитку гуманізму, моралі, художньої культури, що вирізняють першу третину XX століття в історії Піднебесної, вивчав проблеми естетики музики. Китайського естетика першої третини XX століття хвилювали питання краси музики, сутності музичного мистецтва, його жанрових типів та суспільних функцій, розподілу емоцій на види, проблеми співвідношення змісту і форми художніх творів. Хуан Цзи значну увагу приділив питанню взаємодії «чистої» музики (яку 
характеризує іï як «ідеальну»), і музики програмної. У наукових працях китайського знавця музика «чиста» і програмна утворюють два ії види, між якими мають існувати глибинні зв'язки. Показово, що в композиторській творчості Хуан Цзи наявні ті самі зв'язки, помітні у формі втілення змісту, які характерні для його наукових праць музичного естетика. Особливе значення в контексті естетичних думок Хуан Цзи мають розгляд питань зв'язків музики і повсякденного життя. Як головне завдання музики як «великого мистецтва» Хуан Цзи, тлумачив створення портрету народу і суспільства. Згідно естетичним положенням праць першого класика китайського музичного мистецтва, музика не має безпосередніх зв'язків із природними явищами і життям людини. Хуан Цзи тлумачив мистецтво як вираз життя певної доби, підкреслюючи роль історичного фактору в процесі тлумачення краси мистецького стилю та оцінці виконавської техніки художніх творів. Перший класик професійного композиторського мистецтва Піднебесної, Хуан Цзи заклав основи історизму в китайській музичній науціi.

Як фундатор новітнього музичного виховання у Китаї, Хуан Цзи є автором «Підручника по музиці для середньої школи», де виклав основні ідеї щодо музичного виховання у школі.

Висновки. Хуан Цзи - новатор і класик національного музичного мистецтва, фундатор новітньої музичної школи Китаю - заклав основи професійної музичної освіти Китаю, системно охопивши іï напрями. Деякі з них заклали традицію у національній музичній культурі, інші й досі мають унікальне значення в іiі контексті, набувши в ній перспективне значення. Приміром, якщо жанровою настановою китайської художньої пісні є звернення до національної поезії, то Хуан Цзи заклав перспективи розвитку жанру й іноземною (англійською) мовою.

\section{Jimepamypa}

1. 贺绿汀. 回忆黄自先生. 乐坛, 1983, 8:2

(Хе Лютінг. Спогади пана Хуан Цзи // Музична сцена, 1983. № 8. С. 2)

2.14 戴鹏海. 黄自年谱. 音乐艺术1981, 2:17 19

(Д’єн Пенхай. Хуан Цзи. Хронологія // Музичне мистецтво. 1981.№ 2. С. 17 )

3、李岗清 . 探索创建我国民族乐派的先驱和一代宗师—

黄自 $[J]$. 音乐艺术：上海音乐学院学报，2008，2

(Лю Юйцін. Вивчення творчості новатора і великого фундатора національної музичної школи Китаю Хуан Цзи // Музичне мистецтво. 2008. № 2. )

4.冯 芸. 中国第一部清唱剧及其作者——为《长恨歌》问世70周年而作. 苏州大学学报 ( 工科版 ), 2002,12:59

(Фен Вей. Первая ораторія Китаю і їі автор - до 70-річчя «Співу одвічного співчуття» // Музичне мистецтво, 2008. № 2. )

5. 缑瑛．黄自艺术歌曲的美学特征 $[D]$. 华中师范大学，2007.5:38

(Гоу Ін. Естетичні характеристики художніх пісень Хуан Цзи // Центральний Китайський педагогічний університет, 2007. № 5.

Стаття надійшла до редакиї 21.09.2019 р. 